\title{
Predicting the spring abundance distribution of red-legged partridge populations in agricultural regions using environmental models and an application for game management
}

\author{
Victoriano PEIRO'* and Charles P. BLANC ${ }^{2}$ \\ ${ }^{1}$ Department of Ecology, Faculty of Sciences, University of Alicante, 03080 Alicante, Spain; \\ e-mail:v.peiro@ua.es \\ ${ }^{2}$ Laboratory of Zoogeography, B.P. 5043, University of Montpellier-3, 34032-Montpellier Cedex 1, France; \\ e-mail:cp.f.blanc@wanadoo.fr
}

Received 20 September 2010; Accepted 19 May 2011

\begin{abstract}
Several series of available environmental (land use/land cover, agriculture, soil, climate) variables are used in exploratory models to test their use for successful prediction of red-legged partridge (Alectoris rufa L.) abundance in spring. A Geographic Information System and stepwise multiple regression analysis are used to show and predict distribution of this population parameter in an agricultural region of southern France. High spring abundance was observed to be distributed mainly in the central and north-western part of the study area. Two partial models, land use/land cover and agriculture, and a complete model with land use and temperature variables are the most significant and more accurate than any others. The complete model is the best model (lowest Akaike Information Criterion and highest Akaike weight). The potential abundance obtained from this best model shows communes with high Kilometric Abundance Indices (KAI), mainly located in the northwestern part of the region. Partridge abundance was unevenly or irregularly distributed across the study area, which is typical of wildlife species inhabiting complex and changing landscapes limited by various sources of human pressure, such as agriculture, urbanization and game management. A game tool is provided using potential spring abundance to plan the harvest quotas two months before opening the hunting season.
\end{abstract}

Key words: Alectoris rufa, modelling distribution, Kilometric Abundance Index, GIS, southern France

\section{Introduction}

The red-legged partridge (Alectoris rufa L.) is endemic to Europe, where it is confined to south-western parts of the continent. Its status in the southern part of Europe shows higher breeding population sizes in Spain and France than in Portugal and Italy (BirdLife International 2011). The red-legged partridge is classified as SPEC category two (Species of European Conservation Concern) based on its marked population decline and its limited distribution (Aebischer \& Potts 1994, BirdLife International 2004), especially during the second half of the $20^{\text {th }}$ century (Aebischer \& Lucio 1997, Meriggi \& Mazzoni della Stella 2004). Although populations were stable in Portugal and Italy during 1990-2000, this species continued to decline across most of its European range. The highest densities within its current distribution range were found in the southern half of the Iberian Peninsula (Vargas et al. 2006), but the Spanish population suffered about a $25 \%$ reduction during 1990-2000 (BirdLife International 2004, Farfan et al. 2009). Partridge populations in Mediterranean Europe have declined for a variety of reasons, including loss of habitat, overhunting, abandonment of traditional game management techniques, genetic introgression as a result of restocking with different species or hybrids, and disease transmission due to limited sanitary controls when restocking (Ponce-Boutin 2000, Meriggi et al. 2007, Buenestado et al. 2008).

This partridge is the fifth most hunted of French game species and the third if only resident small game species 
are considered (Ponce-Boutin 2000). Nevertheless, its distribution in France is limited to the southern twothirds of the country. According to Farthouat (1983), the species is declining and has become rare in two-thirds of the agricultural regions within its area of distribution in France. This partridge has low abundance in more than $75 \%$ of hunting territories, and it is in regression in $45 \%$ of these territories in the southern part of France (Ponce-Boutin et al. 2006). Novoa (1984) showed that the number of partridges bagged decreased in several sectors of the Languedoc-Roussillon region (southeastern French Mediterranean region). The area under study is confined to the "Département de l'Hérault", the second most important department in red-legged partridges bagged.

Habitat degradation and loss are shown as one main cause of red-legged partridge decline in Europe, mainly due to agricultural intensification or abandonment (Fuller et al. 1995, Pain \& Pienkowski 1997, Aebischer \& Lucio 1997, Meriggi \& Mazzoni della Stella 2004, Reino et al. 2010). European agricultural policies have promoted agricultural transformations and the influence of these changes has not been evaluated sufficiently. Viticulture is predominant in this French region, which has suffered intensive transformations, mainly planted and pulled up vineyards. Other European countries have also suffered (or are going to suffer) similar transformations, thus the present study could be an opportunity to evaluate the influence of these transformations on a wildlife species. Its delicate conservation status and high game value lead to a high demand for data on the spatial ecology of the red-legged partridge. Thus the study of environmental processes at regional scale is important to complement game state (local) studies and to envision a broader management approach (Peiro \& Seva 1993, Peiro \& Blanc 1998, Vargas et al. 2006, Farfan et al. 2009). Geographic Information Systems (GISs) have been playing an increasingly important role in wildlife biology and management at regional level, because they provide the means for storing, displaying and analysing multivariate spatial data, developing predictive models from the relationships among data and extrapolating the potential distribution of species population parameters from models (see Hodgson et al. 1988, Agee et al. 1989, Ferrier \& Smith 1990, Walker 1990, Pereira \& Itami 1991, Mladenoff et al. 1995, Liu et al. 1995, Borralho et al. 2000, Jimenez-Garcia et al. 2006, Cousins 2007).

Furthermore, Peiro \& Blanc (1998) have used GIS environmental/game management databases and discriminant analysis to predict density intervals and population trends (1980 to 1987) of the red-legged partridge in the same study area as this paper. Borralho et al. $(1999,2000)$ incorporated and manipulated redlegged partridge locations and environmental variables in a vector-based GIS of farmlands in Portugal, and some multivariate linear or logistic regression models of partridge detections were fitted using forward stepwise selection. Jimenez-Garcia et al. (2006) related hunting bags of several game species with land uses and landscape indices, which were used as independent variables in linear regression models. Meriggi et al. (2007) used logistic models to plan red-legged partridge reintroduction in central Italy. However, the studies relating habitat factors to this partridge abundance (KAI or density) from line transect census are scarce at regional scale (Peiro \& Seva 1993).

The aim of this study was to predict the distribution of red-legged partridge population within an agricultural region. The use of a Geographic Information System (GIS) to determine whether several series of available environmental habitat variables can be used to prepare predictive models of partridge abundance in spring was of particular interest.

A new final objective that the authors have in mind is to provide a useful tool for red-legged partridge game management. In this way, game administrators could use the potential (predicted) spring abundance for each commune of an agricultural region to plan the harvest quotas some months before opening the hunting season (mid-September to the first week of October, depending on the region and year). These environmental databases and modelling approach would also be useful for other researchers and technicians who are working with resident small game and other wildlife species inhabiting agricultural landscapes.

\section{Study Area}

This study was carried out in "Plaine Viticole du Bas-Languedoc" (code number 471), one of the six agricultural regions in Hérault Department in the south of France. Its $2000 \mathrm{~km}^{2}$ lie on the Mediterranean coast (latitude $43^{\circ} 12^{\prime}-43^{\circ} 44^{\prime} \mathrm{N}$, longitude $3^{\circ} 00^{\prime}-3^{\circ} 10^{\prime}$ $\mathrm{E}$ from Greenwich Meridian), and are divided into 109 French political-administrative districts called communes (see Fig. 1).

The sub-humid Mediterranean climate had a mean monthly precipitation of $45 \mathrm{~mm}$ and temperature of $15{ }^{\circ} \mathrm{C}$ during the study period. The topography is mainly flat or extensively undulating hills and valleys. Dominant soils in the study area are slimy (30\% of surface) and clayey (24\%).

Viticulture is predominant in the region, with vineyards representing about $60 \%$ of the overall surface and $73 \%$ of Useful Agricultural Surface (UAS). Other 
COMMUNES DE LA PLAINE VITICOLE DE L'HERAULT

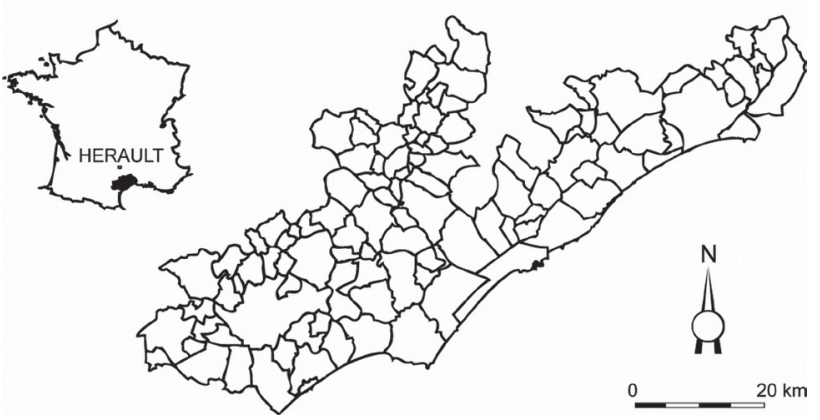

Fig. 1. Map of the study area with communes (INSEE).

important types of agriculture are grasslands (7\%), cereals $(6 \%)$ and fruit orchards $(3 \%)$. Natural or seminatural vegetation is dominated by Mediterranean evergreen shrub lands (6\% of the region's surface) and forests $(5 \%)$. Urban land occupies about $8 \%$ and wetlands about $10 \%$ of the region.

\section{Material and Methods}

\section{Partridge census}

Red-legged partridges were surveyed in 1994 using a method developed by Ricci et al. (1993) for the same area. The method was designed to obtain a Kilometric Abundance Index (KAI) of partridges $/ \mathrm{km}$. The study area was divided into north-south transects, excluding wetlands, coastal areas and large urban areas (see original paper for more details). The transects were surveyed in spring (second half of March). During this period, three replicates of each transect were made by two observers with binoculars who counted the partridges seen at both sides of their slow-moving car (15-20 km/hr), for three hours after dawn or before dusk.

The number of partridges was noted on census cards, and their location within the commune was also noted on a topographical map $(1: 25000)$. The length of the transects in each commune was calculated to obtain spring KAIs. The routes of transects ranged from 3 to $77 \mathrm{~km}$, which mainly depended on (1) the commune size, (2) they crossed the most representative habitats and (3) accessibility of rough tracks across fields.

\section{GIS database development}

A Geographic Information System (GIS) was used as an aid to data management and analysis of partridge population abundance and environmental data. A basemap was assembled with several environmental databases. The base-map was an ARC/INFO commune (INSEE Communes) map digitalized from 1: 50000 topographical maps (IGN 1959). Environmental variables were taken for land use/land cover (LU/LC), soil, agriculture and climate. LU/LC was taken from ARC/INFO Corine Land Cover map (1990) provided by the Soil Laboratory of the National Institute for Agronomical Research (INRA) in Montpellier. The original Corine Land Cover classification was regrouped and recoded up to the second level, except for shrub areas, which were grouped together into one variable. A soil database was generated from an ARC/INFO Languedoc-Roussillon Regional Soil map (Source: INRA Soil Laboratory). Only texture and stoniness were retained as an indirect measure of soil filtration capacity, an important environmental factor for red-legged partridge during the breeding season (ONC 1986).

Both LU/LC and soil cover were overlaid on the basemap using the ARC/INFO UNION function, which enabled generation of the areas of LU/LC or soil type in each commune first and then their percentage of the total commune area. An LU/LC diversity index was also calculated on the base of the Shannon information theory index (Shannon \& Weaver 1949): $\mathrm{H}^{\prime}=-\Sigma$ pi. $\log _{2}$ pi with $\mathrm{pi}=\mathrm{SLC} / \mathrm{SC}$, where SLC is the area (ha) of land cover type in a commune and SC is the total area (ha) of the commune.

A DBASE file on agriculture was provided by the Departmental Agricultural Service of Montpellier (RGA 1988), where the rows were the INSEE commune code numbers and the columns the areas (ha) of different types of cultivated land, and the annual amounts (ha) planted or pulled up in vineyards from 1988 to 1992. Land use by type of agriculture was calculated as a percentage of the area of the commune. The annual mean (1988-1992) percentage of the area of the commune was taken of planted or pulled up vineyards. The mean annual percentage of vineyard loss (LOV) showed the net balance between planted and pulled up vineyard percentages of surface in each commune. The density of tractors per commune (tractors/100 ha) was also calculated as an important indicator of agricultural perturbation of the red-legged partridge breeding season. A climate database was generated using monthly precipitation and temperature data from twenty-seven weather stations distributed over the study area (source: Departmental Climatic Service of Montpellier). Data for the variables assigned to each commune were either taken from the nearest weather station or were interpolated from the two nearest stations. The mean of each variable was then calculated for three critical periods in the redlegged partridge annual cycle when climatic factors are the most important: mating (February-March), nesting (April-May) and rearing of young (June-August).

All databases were a matrix with INSEE numbers as rows and variables as columns. A summary of the 
variables included in each environmental database is presented in Appendix 1. The base-map has been kept for display purposes.

\section{Model design}

Databases were organized in two blocks in the GIS: partridge population (spring abundance) and habitat (LU/LC, agriculture, soil and climate). Given the great diversity of red-legged partridge habitat requirements (ONC 1986, Ponce-Boutin 2000), all variables were considered important on an "a priori" basis for modelling. SOLO software(BMDPStatistical Software, California, USA) was used for all Multiple Linear Regression modelling analyses, and statistical significance was accepted whenever $P<0.05$. A preliminary selection of the variables in each database was carried out to confirm normality and linear patterns, using logarithms or square-root transformations when necessary. Polynomial associations to assess possible curvature or non-linear patterns were not used, as the relationship between independent and dependent variables became sufficiently linear after transformations, and the weighted analysis reduced the influence of outliers (see SOLO Manual, BMDP Statistical Software, California, USA). In addition, the linear regressions can be easily interpreted in statistical and ecological terms by wildlife technical staff and this is the most frequent modelling technique used by the French Game and Wildlife Service (see ONCFS Small Game Reports and Technical Species Notes).

First of all, Pearson's correlation (R) was computed between each pair of explanatory variables, in order to reduce collinearity problems. Next, mainly the correlation matrix (R-squared with other Xs), but also the Variance Inflation Factor, were calculated from all independent variables to examine multi-collinearity in each database. The rules to select the non-collinear variables were: R-squared with other $\mathrm{Xs}<0.7$ and Variance Inflation Factor $<10$.

Two kinds of multiple regression models were developed. The first, called partial models, considered each environmental database separately to predict spring abundance. Then a complete environmental model was developed using all the variables selected in the partial models. This procedure also assured model stability, which requires a high ratio of number of observations per number of variables $(n / p)$. A ratio greater than ten is recommended by most of authors (see Carrasco \& Hernan 1993).

Initial multiple regression analyses were carried out, however, the model building procedure recommended running a robust analysis when outliers were detected in scatter plots and if this weighted analysis improved the unweighted one of each partial and complete model. Next, a stepwise regression analysis (weighted) generated more simplified models. This stepwise procedure stopped when no further addition or deletion of variables would improve the Root Mean Square Error (\% RMSE) by more than one percent (default value). Finally, a new multiple linear regression analysis was run considering weights.

The selection of the suitable fitted partial or complete model was initially performed using F-ratio, adjusted $\mathrm{R}^{2}$ and the observations/variables ratio $(\mathrm{n} / \mathrm{p})$. However, due to the frequent use of Akaike Information Criterion (AIC) in wildlife research, the corrected AIC (AICc), the scaling criterion values $(\triangle \mathrm{AICc})$ and the Akaike weights (wi) were also added to select the final partial/complete models (Akaike 1974, Burnham \& Anderson 2002, Brauwere et al. 2005). The criteria to select the best model, or more parsimonious model, were: the model that had a high adjusted $\mathrm{R}^{2}$, the one with observations/ variables ratio $(n / p)>10$, and finally the lowest AICc and highest wi. The wi are interpreted as the probability that model $i$ was, in fact, the best model for the data (Burnham \& Anderson 2002). Next, the most important predictor variables were individuated by the number of significant models in which they entered, by the sum of wi, and by the significance of their regression coefficients averaged on the selected models.

In order to check the validity of the resulting models, each one was used itself to calculate response variable classification error rates from the original data (see Walker 1990, Pereira \& Itami 1991, Mladenoff et al. 1995, Peiro \& Blanc 1998). To do this, the observed and expected abundance variables were intervalscaled and compared to test goodness-of-fit with the percentage of correct predictions. If each regression model has a general validity the observed and expected values of KAI should be significantly correlated.

\section{Results}

The partridge census crossed 71 communes (65\% of the communes in the region). The spring partridge populations (presence) were distributed over 54 communes (76\% of total census area). The highest spring Kilometric Abundance Indices (KAI) were located in several central, north-western and eastern communes rather than elsewhere in the study region (Fig. 2).

The stepwise regression analysis using spring $\mathrm{KAI}\left(\mathrm{LOG}_{10}(\mathrm{KAI}+1)\right.$ converged on three robust (weighted) environmental models: land use/land cover and agriculture partial models and a complete model (Table 1). Soil $(\mathrm{F}=22.37$, $\mathrm{Df}=2,68, P<$ $0.001)$ and climate $(\mathrm{F}=5.52, \mathrm{Df}=4,57, P<0.001)$ 


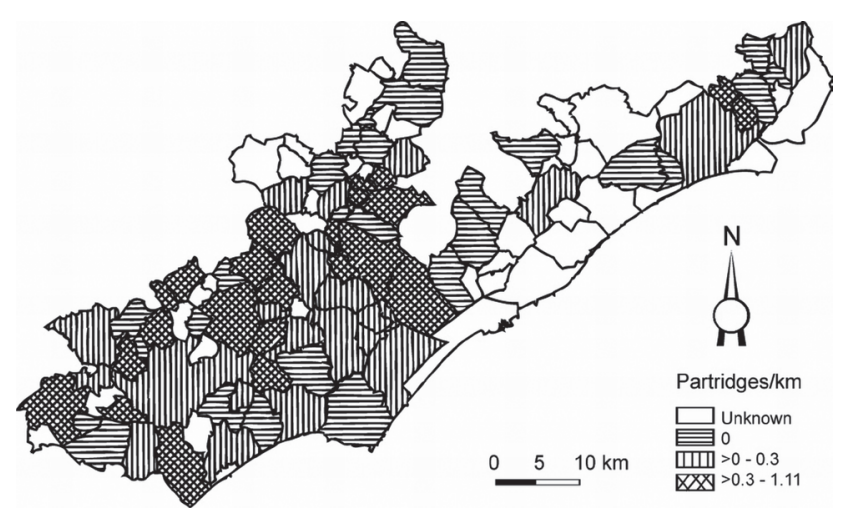

Fig. 2. Distribution of spring abundance of the redlegged partridge observed in the study area.

partial models were significant, but they were not suitable because their goodness-of-fit was low (38 $\%$ and $23 \%$ of explained variance, respectively). Thus, they are not described in Table 1 . This table shows the significances and the explained variances (added value for overall $\mathrm{R}^{2}$ ) for the selected variables, and the main criteria to choose the best fitted model rather than the model with the significant and selected variables for these three previously selected models. Testing all possible models is not the best strategy in model selection, although

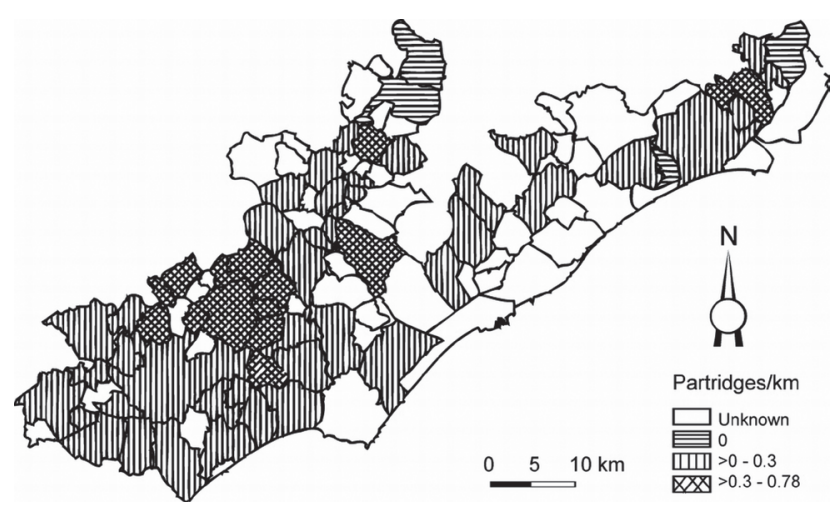

Fig. 3. Potential distribution of spring abundance predicted for the red-legged partridge by complete model in the study area.

discussion concerning this topic is still problematic in ecological modelling (see e.g. Reino et al. 2009). No partial/complete model had no correlation at all between residuals and predicted abundance, which also means a good fit of these models to the raw data. The more influential (higher added value for overall $\mathrm{R}^{2}$ ) selected variables in the total explained variance for each of the three selected models were: discontinuous urban lands $\left(\mathrm{R}^{2}=26 \%\right)$ in land use/land cover model; mean monthly temperature during rearing of young $\left(\mathrm{R}^{2}=19 \%\right)$ in complete

Table 1. Selected partial and complete models, and their statistical descriptors, obtained by using stepwise linear regression to predict the spring abundance (KAl) distribution of the red-legged partridge in an agricultural region of southern France.

\begin{tabular}{|c|c|c|c|c|c|c|c|c|c|c|}
\hline Model & $\begin{array}{l}\text { Selected variables } \\
\text { in each fitted model }\end{array}$ & B Coefficients & $P$ var & $\mathrm{R}^{2} \mathrm{var}$ & $\begin{array}{l}\text { F-ratio } \\
\text { (Df) } \\
P\end{array}$ & $\mathrm{R}^{2} \mathrm{adj}$ & $\mathrm{n} / \mathrm{p}$ & AICc & $\triangle \mathrm{AICc}$ & wi \\
\hline Land use/ & Interception value & 0.0709 & 0.144 & & 19.96 & 0.57 & 14.20 & 5.80 & 2.05 & 0.24 \\
\hline \multirow{5}{*}{ land cover } & Continuous Urban & -0.1212 & 0.002 & 0.06 & $(5,65)$ & & & & & \\
\hline & Discontinuous Urban & -0.1457 & 0.001 & 0.26 & $\mathrm{P}<0.001$ & & & & & \\
\hline & Vineyard & 0.0461 & 0.002 & 0.10 & & & & & & \\
\hline & Broad-leaf Forest & 0.0354 & 0.008 & 0.04 & & & & & & \\
\hline & Shrub Land & -0.0574 & 0.001 & 0.15 & & & & & & \\
\hline \multirow[t]{7}{*}{ Agriculture } & Interception value & 0.2341 & 0.001 & & 17.10 & 0.58 & 11.83 & 8.17 & 4.42 & 0.08 \\
\hline & Permanent Crop-Fruit & 0.0079 & 0.001 & 0.04 & $(6,64)$ & & & & & \\
\hline & Uncultivated Field & -0.0026 & 0.003 & 0.03 & $\mathrm{P}<0.001$ & & & & & \\
\hline & Irrigated Land & -0.0423 & 0.003 & 0.16 & & & & & & \\
\hline & Useful Agric. Surface & -0.0011 & 0.001 & 0.15 & & & & & & \\
\hline & Plantation Vineyard & 0.0323 & 0.001 & 0.17 & & & & & & \\
\hline & Tractor Density & -0.0552 & 0.002 & 0.07 & & & & & & \\
\hline \multirow[t]{5}{*}{ Complete } & Interception value & -2.0156 & 0.001 & & 20.51 & 0.56 & 15.50 & 3.75 & 0 & 0.68 \\
\hline & Discontinuous Urban & -0.1243 & 0.001 & 0.18 & $(4,57)$ & & & & & \\
\hline & Vineyard & 0.1463 & 0.002 & 0.12 & $\mathrm{P}<0.001$ & & & & & \\
\hline & MEMTY $^{(a)}$ & 0.1045 & 0.001 & 0.19 & & & & & & \\
\hline & MAMTY (a) & -0.0153 & 0.001 & 0.10 & & & & & & \\
\hline
\end{tabular}

Explanations: Variable statistics: B Coef.: Regression coefficients; Pvar: Probability for each explanatory variable added to the model. $R^{2}$ var: $R$-Squared added as each explanatory variable is entered in the regressión equation. (a) mean (MEMTY) and maximum (MAMTY) monthly temperature during rearing of young.

Model Statistics: F-ratio, F-statistic for testing all $\beta$ 's = 0; $D f$, degrees of freedom; $P$, probability level; $R^{2}$ adj, adjusted $R$-Squared; $n / p$, ratio of number of observations (n) per number of variables (p) included in the model; AlCc, corrected Akaike index; $\triangle A I C$, scaling criterion values, and wi, Akaike weights. 
model; and mean annual vineyard plantation $\left(\mathrm{R}^{2}=\right.$ $17 \%$ ) in agriculture model.

On the selection of the best model from the three suitable fitted models (partial or complete), the simplest one should be preferred by the application of the "principle of parsimony" (see e.g., Brauwere et al. 2005). Thus the complete model was selected, due to all three final models having similar goodness-of-fit (nearly $60 \%$ of the explained variance $\mathrm{R}^{2} \mathrm{adj}$ ), good $\mathrm{n} / \mathrm{p}$ ratios and welladjusted to the number of variables, but the complete model showed (see Table 1) the lowest AIC (AICc = 3.75 ) and the highest probability (wi $=0.68)$ to be the best model. The land use/land cover model had low Akaike weight, but it still had substantial support/evidence $(\triangle \mathrm{AICc} i \leq 2)$. The agriculture model had considerably less support $(4 \leq \triangle \mathrm{AICc} i \leq 7$, see Burnham \& Anderson 2002). The most important predictor variables (see Methods) were discontinuous urban land and vineyard (both in land use/land cover and complete models, $\sum$ wi $=0.92$, average significance: discontinuous urban $=$ 0.001 and vineyard $=0.002$ ).

The classification in intervals of abundance predicted from the abundance observed was about $50 \%$ in all selected models. All the models had a high rate of misclassification for $\mathrm{KAI}=0$, which was the least predicted class. $\mathrm{KAI}>0$ to 0.3 was predicted the most and the best by all the models. The greatest abundance predicted $(0.78$ partridges $/ \mathrm{km})$ was still lower than that observed (1.11 partridges $/ \mathrm{km}$ ). Abundance predicted by all partial or complete models was intercorrelated $(P<0.001)$ and correlated with observed abundance, which means environmental models made good predictions. The potential abundance from the best environmental model (complete, see Fig. 3) showed more communes with high KAI mainly located in the north-western part of the study area.

\section{Discussion}

The population abundance distribution pattern was uneven or irregular and no large area clusters (subzones) or parameter gradients across the study area could be differentiated. This is typical of wildlife species inhabiting complex changing landscapes, which are limited by several sources of human pressure (agricultural, urban). Furthermore, different red-legged partridge game management techniques may be a factor in explaining the uneven distribution pattern observed in the population parameter analysed, but the use of this source of information is restricted in the present paper (see Peiro \& Blanc 1998). However, the game factors formed part of the residuals not explained by each environmental model, but did not affect the model itself. Several environmental characteristics were found to be apparently good predictors of spring abundance distribution. The ecological significance of the variables selected for the models is discussed in an analysis of their biological suitability. The most important predictor variables were discontinuous urban land and vineyard (see Results), both in the most plausible models (complete and land use/land cover). The significant importance of discontinuous urban land is ecologically consistent (Peiro 1992). Thus an urbanization (tourist and secondary housing) scattered into the agricultural landscape had a negative influence on partridge abundance in the study area, due to the quantitative (area) and qualitative (perturbation) loss of available habitat. The positive effect of vineyards is also consistent with general knowledge of redlegged partridge ecology (see ONC 1986, Peiro 2003, Ponce-Boutin et al. 2006, Meriggi et al. 2007) and it was a favourable discriminator in the Department of Hérault (Garcia 1990) as well as in the area of this study (Peiro \& Blanc 1998). The highest abundance of partridges within the Mediterranean part of France was found in agricultural areas with high dominance of vineyards and/or cereal crops (Ponce-Boutin et al. 2006). The habitat importance of vineyards is more related to its field structure as shelter habitat, ensuring good protection rather than food resource availability for partridges.

Two temperature descriptors were significant during rearing of young in the best (most plausible) complete regression model. Higher mean monthly temperature during this period was a favourable factor in survival of the young (ONC 1986) and it could produce greater abundance the following spring if autumnwinter mortality was low. However, if maximum temperatures were too high during this period, the amount of vegetation available as food later in the summer could decrease. Shrub land was the second most influential (see Table 1) selected variable in land use/land cover model. Shrub lands are important as a shelter habitat if vegetation cover is not high (Peiro 2003, Tapia \& Dominguez 2007). Thus this land use type is negatively associated with partridge abundance, because shrub cover has become quite high during the last decades in this French Mediterranean region (Ponce-Boutin et al. 2006). This fact is a relevant issue for this partridge and for the overall Mediterranean farmland birds and it is often linked with agricultural abandonment (Ponce-Boutin 2000, Morgado et al. 2010, Reino et al. 2010). In this context, the most notable long-term trends for rural depopulation and agricultural abandonment in poorly productive areas are generally followed by scrub encroachment 
and afforestation (Santos et al. 2006). Moreover, Jimenez-Garcia et al. (2006) found that red-legged partridges were positively influenced by the surface of old abandonment areas in other Mediterranean agrosystems (southeastern Spain). Nevertheless, this response showed a relative preference for dry and low colonizing shrubs in the Alicante Province and this type of shrubland could provide some cover and food for partridges.

The positive influence of broad-leaved forests could be related to the fact that these forests in the study region are mainly remnants, found either as small woods or riparian corridors within the agricultural matrix, which play a role as shelter and nesting habitats for red-legged partridges. Reinforcing this topic, Meriggi et al. (2007) found that zones with more than $50 \%$ of woods, scrubland, and urbanized land were considered unsuitable for red-legged partridges in Italy. Furthermore, hedgerow length had a positive effect on the presence of red-legged partridge spring pairs. They also found high-density areas for redlegged partridge that were characterized by higher percentages, among other land uses, of vineyards, woods and by higher values of habitat diversity and ecotone index. Moreover, this partridge needed complex landscape areas composed of irregular edges with a low level of human influence (Jimenez-Garcia et al. 2006). Our results were also supported by the observation that several ground-nesting farmland birds showed positive or neutral responses to wooded edges (Reino et al. 2009).

Although the agriculture model was less plausible than others, some discussion on its selected variables should be considered important in terms of agricultural management and partridge habitat relationships. Then, unirrigated fruit orchards (positively related) may be considered a favourable habitat for red-legged partridge of the selected agricultural model variables, and irrigated land (negatively related) as an unsuitable habitat (Ponce-Boutin 2000, Borralho et al. 2000, Peiro 2003). Thus partridges showed some habitat selection for dry fruit groves, mainly used as a feeding habitat in Mediterranean regions. Uncultivated fields and predominant agricultural areas in use were also negatively related to partridge abundance, due to the fact that uncultivated land included large areas of temporarily abandoned agricultural lands where the herbaceous layer became high and dense and therefore unsuitable as feeding and cover habitat. The agricultural area in use represented more surface of intensive agriculture and may be considered as an unfavourable factor in Mediterranean agrosystems of France (Ponce-
Boutin 2000, Ponce-Boutin et al. 2006).

Recent planting in vineyards had the opposite effect to uncultivated fields in this study area, which is ecologically consistent because they represent more open agricultural land. The present study shows a positive influence of this agricultural transformation on the red-legged partridge habitat, which can be considered as additional support for the positive influence of vineyards on partridge population shown in the complete model (see above). Therefore, agriculture and game administrators might consider this factor in European agricultural regions that are going to develop plantation in vineyards. However we would be cautious in this respect because the opposite effect (negative influence) may also be true for some specialist habitat birds or for the overall species richness of farmland bird communities (see Reino et al. 2009, 2010). Conversely, no significant influence was found for pulled up vineyards, thus the positive influence of European Policy to promote set-a-side fields from the less productive or low quality vineyards might not be shown. Only tractor density was selected by the discriminant model (Peiro \& Blanc 1998) and the present modelling technique. This variable should therefore be considered to be an important factor in partridge perturbation, as a consequence of the intensification of agriculture in France (Ponce-Boutin 2000). Agricultural intensification and land abandonment represent an important threat for farmland wildlife in southern Europe (Bignal \& McCracken 1996, Pain \& Pienkowski 1997, Aebischer \& Lucio 1997, Meriggi \& Mazzoni della Stella 2004, Reino et al. 2010). According to Reino et al. (2010) the same agricultural policies may be favourable for some species of conservation concern but detrimental to other farmland birds. Consequently, they cannot be assumed to bring uniform conservation and management benefits (Suárez-Seoane et al. 2002, Báldi et al. 2005). Efforts are thus needed for preventing undesired consequences of agricultural policies designed at the European scale, but carried out through the implementation of regional or local agri-environmental schemes (Stoate et al. 2009).

From a methodological point of view, the spatial unit is a critical decision in GIS analysis. Either environmental or wildlife population units are usually chosen for this type of study (see e.g., Pereira \& Itami 1991). Although the commune is a political unit, it is the most representative hunting administration unit in this study area and game management variables mainly refer to them (Peiro \& Blanc 1998). In this context, when the communes border one another, spatial 
autocorrelation may have some influence (loss) on the power of models. However, the models constructed with this type of spatially structured variables may have the same validity (Farfan et al. 2009) as those where spatial autocorrelation is explicitly considered (e.g., Dormann 2007). The spatial variables could reveal some geographical trends in distribution, which are related to historical events or migrations (Legendre 1993, Real et al. 2003) and are outside management scope. Furthermore, Kissling \& Carl (2008) have shown that the selection of spatial autoregressive models can strongly influence parameter estimates, which might be even worse than parameter estimates from Ordinary Least Square regressions.

Another methodological subject was related to whether KAI might be dependent on sampling effort. Therefore, in order to ensure that different survey efforts (3 to $77 \mathrm{~km}$ ) are not acting as a statistical artefact, the possible associations of abundance (KAI) with distance $(\mathrm{km})$ survey in each commune were assessed. No significant correlation was found for Spring KAI-Transect length $(\mathrm{r}=0.038, \mathrm{Df}=69$, $P>0.05$ ). Thus sampling effort does not have any spurious effect on our Spring KAI and it would not be necessary to include it as an offset variable in the selected models.

\section{Management implications}

As previously mentioned, the final objective of our study is to provide a useful tool to enable game administrators to use potential spring abundance to plan harvest quotas some months before the hunting season opens. Consequently, use of the regression plots proposed by Birkan (1979, see also in Peiro 2003) to obtain hunting quotas in French populations of red-legged partridge is recommended. Game technicians could use the following procedure to develop this target:

1. Game technicians should obtain their own data about the four environmental variables selected in our complete model (see Table 1). The model equation (LOGKAI $=-2.0156-0.1243$ LOG-Discontinuous urban lands $(\%)+0.1463$ LOG-Vineyards $(\%)+$ 0.1045 mean monthly temperature during rearing of young -0.0153 maximum monthly temperature during rearing of young) could be used to obtain the potential spring KAI in their hunting territories. The confidence interval for the prediction of spring KAI $\left(\right.$ after transformation $=\left(\right.$ Antilogarithm $\left.\left.{ }_{10}\right)-1\right)$ at the $\mathrm{a}=0.05$ level of significance ranges from 0.15 to 0.22 partridges $/ \mathrm{km}$, although the highest abundance predicted by this model is 0.78 partridges $/ \mathrm{km}$ ).
2. Using the model of linear regression standardized for constant equal to zero (Density $=6.696 \mathrm{KAI}$, $\mathrm{R}^{2}=0.68, P<0.01$ ), proposed by Ricci (1989) in the same French Mediterranean region, would allow the game technicians to transform this potential spring KAI into an absolute density (partridge pairs per 100 ha). This model can convert a relative abundance (KAI) from the car line-transect census into a density from the battue (driven) total census (Ricci 1982, Bibby et al. 1992). This model had already been validated by Ricci (1989) in several areas inside the region of study. Then, he had found that the estimated density differed from 0.2 to 1 pair per 100 ha from pair density in the field. The partridge density interval in Birkan's plot ranges from zero to 30 pairs per 100 ha.

3. The spring density (couples/100 ha) obtained is inserted into the Birkan's plot and related to the age-ratio obtained from a summer sampling. This results in a harvesting quota showing the number of partridges allowed to be hunted per 100 ha during the next hunting season. It is computed to ensure a constant pair density in the following spring, which is consistent to sustainable harvesting (see more details in Birkan 1979). The upper limit for hunting quotas in Birkan's plot is 100 partridges per 100 ha.

With the above approach, game technicians would not need to spend time and money on conducting spring counts. They only need to carry out a simple sampling effort to estimate the age-ratio in the field. Using this approach to calculate the hunting quota simplifies and makes it easier for administrators to manage their partridge populations two months (second half of July to the beginning of August) before opening the hunting season. Furthermore, it would not be necessary to develop environmental models to predict the summer parameters and their application on game management to calculate hunting quotas.

The main purpose of this study was not to provide definitive statements on habitat-abundance relationships, but rather to describe the role which the several approaches to modelling, together with a Geographic Information System, can play in assisting ecologists and administrators in the display and analysis of red-legged partridge distribution data. Finally, the GIS information could be used to identify partridge management priorities, even for other resident small game species, in an integrated natural resource management plan for similar agricultural regions in the southern part of Europe. In this context, the mean and range of environmental variables might be useful to specify the external validity of the models in other regions. Thus the selected variables in our best suitable 
model (complete) showed $4.2 \%$ of mean percentage of commune area for Urban Discontinuous land use (min$\max =0-22.5 \%), 70.0 \%$ for mean Vineyard land use (min-max $=28.5-5.1 \%$ ), and the monthly temperatures during rearing of young ranged from 20.5 to $31.4{ }^{\circ} \mathrm{C}$ $\left(\right.$ MEMTYmean $=22.3{ }^{\circ} \mathrm{C}$ and MAMTYmean $=28.4^{\circ} \mathrm{C}$ ).

\section{Acknowledgements}

This work was funded through a Cooperative Agreement among "Laboratoire de Zoogéographie-Université de Montpellier 3" (France), "Conselleria d'Educació y Ciència de la Generalitat Valenciana (Spain) and "Fundación Cultural CAM de Alicante" (Spain). We are particularly grateful to J.C. Ricci (IMPCF), L.
Aymard and other technical staff of Hérault Hunters Federation who collaborated in partridge census. We are also grateful for data and GIS coverage provided by J.C. Codant and A. Cames (DDA-Montpellier), M. Bornand and P. Falipou (INRA-Montpellier), J. Lorblanchet (MétéoFrance-Montpellier), L. Davy (Université Montpellier 3) and Y. Houelleu (IGNMontpellier). Requested geographical maps were used with permission from the National Geographic Institute (IGN). We received GIS assistance from R. Quissac (Laboratoire de Zoogéographie-Montpellier) and J.E. Martínez/A. Belda (Laboratorio de Cartografia de Recursos Naturales-Alicante). We would also like to thank an anonymous referee for a previous review.

\section{Literature}

Aebischer N.J. \& Potts G.R. 1994: Red-legged partridge Alectoris rufa. In: Tucker G.M. \& Heath M.F. (eds.), Birds in Europe: their conservation status. BirdLife International, Cambridge: 214-215.

Aebischer N. \& Lucio A. 1997: Red-legged partridge (Alectoris rufa). In: Hagemeijer E.J.M. \& Blair M.J. (eds.), The EBBC atlas of European breeding birds: their distribution and abundance. Poyser, London: 208-209.

Agee J.K., Stitt S.C.F., Nyquist M. \& Root R. 1989: A geographic analysis of historical grizzly bear sightings in the North Cascades. Photogrammetric Engineering \& Remote Sensing 55: 1637-1642.

Akaike H. 1974: A new look at the statistical model identification. IEEE Transactions on Automatic Control 19 (6): $716-723$.

Báldi A., Batáry P. \& Erdös S. 2005: Effects of grazing intensity on bird assemblages and populations of Hungarian grasslands. Agric. Ecosyst. Environ. 108 (2005): 251-263.

Bibby C.J., Budgess N.D. \& Hill D.A. 1992: Bird census techniques. Academic Press, London.

Bignal E.M. \& McCracken D.I. 1996: Low-intensity farming systems in the conservation of the countryside. J. Appl. Ecol. 33: 413-424.

BirdLife International 2004: Birds in the European union: a status assessment. Bird Life International, Wageningen, The Netherlands.

BirdLife International 2011: Species factsheet: Alectoris rufa. Downloaded from http://www.birdlife.org

Birkan M. 1979: Perdrix grises et rouges. De chasse et d'élevage. La Maison Roustique, Paris.

Borralho R., Stoate C. \& Araújo M. 2000: Factors affecting the distribution of red-legged partridges Alectoris rufa in an agricultural landscape of southern Portugal. Bird Study 47: 304-310.

Borralho R., Carvalho S., Rego F. \& Pinto P.V. 1999: Habitat correlates of red-legged partridge (Alectoris rufa) breeding density on mediterranean farmland. Revue Ecologie (Terre Vie) 54: 59-69.

Brauwere A., Ridder F., Pintelon R., Elskens M., Schoukens J. \& Baeyens W. 2005: Model selection through a statistical analysis of the minimum of a weighted least squares cost function. Chemometrics and Intelligent Laboratory Systems 76: 163-173.

Buenestado F.J., Ferreras P., Delibes-Mateos M., Tortosa F.S., Blanco-Aguiar J.A. \& Villafuerte R. 2008: Habitat selection and home range size of red-legged partridges in Spain. Agric. Ecosyst. Environ. 126: 158-162.

Burnham K.P. \& Anderson D.R. 2002: Model selection and multimodel inference: a practical informationtheoretic approach. Springer, New York.

Carrasco J. \& Hernan M. 1993: Estadística multivariante en ciencias de la vida. Ciencia 3, Madrid.

Corine Land Cover 1990: Corine Land Cover France Project. ARC/INFO digital maps. National Institute for Agronomical Research (INRA). Montpellier.

Cousins S. 2007: Landscape ecology and GIS. Taylor \& Francis, London.

Dormann C.F. 2007: Effects of incorporating spatial autocorrelation into the analysis of species distribution data. Global Ecology and Biogeography 16: 129-138.

Farfan M.A., Vargas J.M., Guerrero J.C., Duarte J. \& Real R. 2009: Improving management plans by downscaling hunting yield models: a case study with the red legged partridge in southern Spain. Wildl. Biol. 15: 68-79. 
Farthouat J.P. 1983: Résultats des expériences menées en France sur la perdrix rouge (Alectoris rufa L.). Bulletin Mensuel Office National Chasse 69: 10-15.

Ferrier S. \& Smith A.P. 1990: Using geographical information systems for biological survey design, analysis, and extrapolation. Australian Biologist 3: 105-116.

Fuller R.J., Gregory R.D., Gibbons D.W., Marchant J.H., Wilson J.D., Baillie S.R. \& Carter N. 1995: Population declines and range contractions among lowland farmland birds in Britain. Conserv. Biol. 9: 1425-1441.

Garcia A. 1990: Évolution des populations de perdrix rouge (Alectoris rufa) dans les départements de l'Aude et de l'Hérault. Impact de la régression viticole. Doc. ONC, Montpellier.

Hodgson M.E., Jensen J.R., Mackey H.E., Jr. \& Coulter M.C. 1988: Monitoring wood stork foraging habitat using remote sensing and geographic information systems. Photogrammetric Engineering \& Remote Sensing 54: 1601-1607.

IGN 1959: Topographical maps $1:$ 50000. Institut Géographique National. Montpellier.

Jimenez-Garcia D., Martinez-Perez J.E. \& Peiro V. 2006: Relationship between game species and landscape structure in the SE of Spain. Wildlife Biology in Practice 2: 48-62.

Kissling W.D. \& Carl G. 2008: Spatial autocorrelation and the selection of simultaneous autoregressive models. Global Ecology and Biogeography 17: 59-71.

Legendre P. 1993: Spatial autocorrelation: trouble or new paradigm? Ecology 74: 1659-1673.

Liu J., Dunning J.B. \& Pulliam H.R. 1995: Potential effects of a forest management plan on Bachman's sparrow (Aimophila aestivalis): linking a spatially explicit model with GIS. Conserv. Biol. 9: 62-75.

Meriggi A. \& Mazzoni della Stella R. 2004: Dynamics of a reintroduced population of red-legged partridges Alectoris rufa in central Italy. Wildl. Biol. 10: 1-9.

Meriggi A., Mazzoni della Stella R., Brangi A., Ferloni M., Masseroni E., Merli E. \& Pompilio L. 2007: The reintroduction of grey and red-legged partridges (Perdix perdix and Alectoris rufa) in central Italy: a metapopulation approach. Italian J. Zool. 74: 215-237.

Mladenoff D.J., Sickley T.A., Haight R.G. \& Wydeven A.P. 1995: A regional landscape analysis and prediction of favorable gray wolf habitat in the Northern Great Lakes region. Conserv. Biol. 9: 279-294.

Morgado R., Beja P., Reino L., Gordinho L., Delgado A., Borralho R. \& Moreira F. 2010: Calandra lark habitat selection: strong fragmentation effects in a grassland specialist. Acta Oecol. 36: 63-73.

Novoa C. 1984: Statut de la perdrix rouge en Languedoc-Roussillon. Résultats de l'enquête national 1980. Bulletin Mensuel Office National Chasse 83: 37-39.

ONC 1986: La perdrix rouge. Note technique, fiche $n^{\circ}$. 39, supplément au Bulletin Mensuel Office National Chasse 106: 1-12.

Pain D.J. \& Pienkowski M.W. (eds.) 1997: Farming and birds in Europe. The common agricultural policy and its implications for bird conservation. Academic Press, London.

Peiro V. 1992: Ecología de las poblaciones de perdiz roja (Alectoris rufa) en la provincia de Alicante y su aplicación a la gestión cinegética. Publicaciones de la Universidad de Alicante, Tesis Doctoral, Alicante.

Peiro V. 2003: Gestión ecológica de recursos cinegéticos. Publicaciones de la Universidad de Alicante, Monografias, Alicante.

Peiro V. \& Seva E. 1993: L'abondance de la Perdrix rouge dans la province d'Alicante et les facteurs que la conditionnent. In: Thompson I.D. (ed.), Proceedings of XXI Congress of International Union of Game Biologist, Vol. 2. Thompson Educational Publishing, Inc, Halifax: 132-138.

Peiro V. \& Blanc Ch.P. 1998: Système d'information géographique et gestion de la faune sauvage: analyse de l'abondance de la perdrix rouge (Alectoris rufa) dans la plaine viticole de l'Hérault (France). Gibier Faune Sauvage/Game \& Wildlife Science 15: 355-378.

Pereira J.M.C. \& Itami R.M. 1991: GIS-based habitat modeling using logistic multiple regression: a study of the Mt. Graham red squirrel. Photogrammetric Engineering \& Remote Sensing 57: 1475-1486.

Ponce-Boutin F. 2000: La perdrix rouge. Faune Sauvage 251: 46-53.

Ponce-Boutin F., Brun J.C. \& Ricci J.C. 2006: La perdrix rouge et sa chasse en région méditerranéenne française: résultats d'une enquête. Faune Sauvage 274: 40-47.

Real R., Barbosa A.M., Porras D., Kin M.S., Márquez A.L., Guerrero J.C., Palomo L.J., Justo E.R. \& Vargas J.M. 2003: Relative importance of environment, human activity and spatial situation in determining the distribution of terrestrial mammal diversity in Argentina. J. Biogeogr. 30: 939-947. 
Reino L., Beja P., Osborne P.E., Morgado R., Fabião A. \& Rotenberry J.T. 2009: Distance to edges, edge contrast and landscape fragmentation: interactions affecting farmland birds around forest plantations. Biol. Conserv. 142: 824-838.

Reino L., Porto M., Morgado R., Moreira F., Fabião A., Santana J., Delgado A., Gordinho L., Cal J. \& Beja P. 2010: Effects of changed grazing regimes and habitat fragmentation on Mediterranean grassland birds. Agric. Ecosyst. Environ. 138: 27-34.

RGA 1988: Recensement Général Agricole. Agriculture databases. Departmental Agricultural Service. Montpellier.

Ricci J.C. 1982: Quelques aspects de l'eco-ethologie de la perdrix rouge (Alectoris tufa L.). Doctoral Thesis, INRA, Paris-Griñon.

Ricci J.C. 1989: Une méthode de recensement des perdrix rouges (Alectoris tufa L.) au printemps par indice kilométrique d'abondance (IKAPRV) dans le Midi-Méditerranéen. Gibier Faune Sauvage 6: 145-158.

Ricci J.C., Aymard L., Melac O., Bartherote A., Kalifa L., Llopez Y. \& Rubio N. 1993: Effectifs au printemps et production de jeunes chez la perdrix rouge en 1993 à l'échelle d'une région agricole de l'Hérault: La Plaine Viticole du Bas Languedoc. Doc. IMPCF, Nimes.

Santos T., Tellería J.L., Dias M. \& Carbonell R. 2006: Evaluating the benefits of CAP reforms: can afforestations restore bird diversity in mediterranean Spain? Basic and Applied Ecology 7: 483-495.

Shannon C.E. \& Weaver W. 1949: The mathematical theory of communication. University of Illinois Press, Urbana.

Stoate C., Baldi A., Beja P., Boatman N.D., Herzon I., van Doorn A., de Snoo G.R., Rakosy L. \& Ramwell C. 2009: Ecological impacts of early $21^{\text {st }}$ century agricultural change in Europe - a review. J. Environ. Manage. 91: 22-46.

Suárez-Seoane S., Osborne P. \& Alonso J.S. 2002: Large-scale habitat selection by agricultural steppe birds in Spain: identifying species-habitat responses using generalised additive modelling. J. Appl. Ecol. 39: $755-771$.

Tapia L. \& Dominguez J. 2007: Broad-scale habitat use by red-legged partridge (Alectoris rufa) in a lowdensity area in northwestern Spain. Eur. J. Wildl. Res. 53: 178-182.

Vargas J.M., Guerrero J.C., Farfan M.A., Barbosa A.M. \& Real R. 2006: Land use and environmental factors affecting red-legged partridge (Alectoris rufa) hunting yields in southern Spain. Eur. J. Wildl. Res. 52: 188-195.

Walker P.A. 1990: Modelling wildlife distributions using a geographic information system: kangaroos in relation to climate. J. Biogeogr. 17: 279-289.

Appendix 1. Variables included in environmental databases (transformations are shown for variables selected for any model).

Land use/land cover: logarithm of continuous urban land (LOGCUR), logarithm of discontinuous urban and artificial surfaces (LOGDUR), arable lands (ARL), logarithm of vineyards (LOGVIN), fruit orchards (FRO), heterogeneous agricultural lands (HAL), logarithm of broad-leaved forests (LOGBLF), coniferous forests (COF), logarithm of shrub lands (LOGSHL), open areas (OPA), wetlands (WET), land use/land cover diversity index (LDI).

Agriculture: cereals (CER), industrial crops (IND), leguminous crops (LEG), forage as main crop (FOC), grasslands (GRA), flowers and ornamental plants (FOP), vineyards (VIS), permanent crops and fruit orchards (PCF), uncultivated fields (UCF), fruit orchards (six species, FR6), ploughed fields (PLF), logarithm of irrigated land (LOGIRL), usable agricultural surface (UAS), mean annual vineyard plantation (PLV), mean annual pulled up vineyard (PUV), mean annual percentage of vineyard loss (LOV), square-root of tractor density (SRTRD).

Soil: square-root of Clay (SRCLA), slimy (SLI), sandy (SAN), clay-slimy (CLSL), clay-rocky (CLRO), slimesandy (SLSA), slime-rocky (SLRO), $0 \%$ stony (STO0), > 0-10 \% stony (STO1), > 10-20\% stony (STO2), > 20-30 \% stony (STO3), > 30-50\% stony (STO4).

Climate: the following variables were calculated for three periods (mating, nesting and rearing of young) in the annual cycle of the red-legged partridge: mean monthly precipitation, mean monthly maximum daily precipitation, mean monthly days with precipitation, minimum monthly temperature, mean monthly temperature, maximum monthly temperature. 